\title{
A comparative study of the results of the lateral internal anal sphincterotomy vs manual dilatation of anus for chronic anal fissure.
}

\author{
1. MBBS, FCPS \\ Assistant Professor Surgery \\ Sargodha Medical College, \\ Sargodha. \\ 2. MBBS, FCPS \\ Assistant Professor Surgery \\ Sargodha Medical College, \\ Sargodha. \\ 3. MBBS, FCPS \\ Associate Professor Surgery \\ University Medical \& Dental College, \\ Faisalabad. \\ 4. MBBS, FCPS \\ Associate Professor Surgery \\ Sargodha Medical College, \\ Sargodha. \\ 5. MBBS, DA \\ Assistant Professor Anesthesia \\ Sargodha Medical College, \\ Sargodha. \\ 6. MBBS, DA \\ Assistant Professor Anesthesia \\ Sargodha Medical College, \\ Sargodha. \\ Correspondence Address: \\ Dr. Nazim Hayat \\ House No. 4, Doctors Colony Social \\ Security Hospital, \\ Madina Town, Faisalabad. \\ drnazimhayat25@yahoo.com \\ Article received on: \\ 22/07/2020 \\ Accepted for publication: \\ 02/09/2020
}

\begin{abstract}
Allah Nawaz', Khalid Mahmood², Nazim Hayat ${ }^{3}$, Ahmad Hassan Khan ${ }^{4}$, Asad Rizwan Rana ${ }^{5}$, Raza Farooq ${ }^{6}$

ABSTRACT... Objectives: To compare the results of surgical treatment of chronic anal fissure after lateral internal sphincterotomy with manual dilatation of anus. Study Design: Randomized Controlled Prospective study. Setting: Department of Surgery District Teaching Hospital Sargodha, Pakistan. Period: April 2018 to Feb 2019. Material \& Methods: Patients were divided into two groups by lottery method. The procedures were performed using standard protocols after obtaining written informed consent. 50 patients underwent lateral internal anal sphincterotomy (Group 1) and 50 patients manual dilatation of anus (Group 2). Patients having atypical anal fissures associated with other diseases were excluded from this study. We assessed both groups for persistence of symptoms, complications and better satisfaction in terms of surgical techniques. Results: All patients became symptoms free within 07-14 days of surgery. Urinary retention was noted in $2(4 \%)$ patients in lateral internal sphincterotomy and $2(4 \%)$ in manual dilatation of anus. Temporary flatus Incontinence was noted in $2(4 \%)$ patient of lateral internal sphincterotomy and 2(4\%) in manual dilatation of anus. Faecal soiling was observed in $1(2 \%)$ patient of lateral internal sphincterotomy. No recurrence, anal stenosis, hemorrhage, infection of wound, pain and bleeding associated with defecation was seen in both groups. Conclusion: Both lateral internal sphincterotomy and manual dilatation of anus techniques are effective.
\end{abstract}

Key words: Anal Sphincter, Chronic Anal Fissure, Lateral Internal Anal Sphincterotomy, Manual Dilatation of Anus.

Article Citation: Nawaz A, Mahmood K, Hayat N, Khan AH, Rana AR, Farooq R. A comparative study of the results of the lateral internal anal sphincterotomy VS manual dilatation of anus for chronic anal fissure. Professional Med $\mathrm{J}$ 2020; 27(11):2295-2299. https://doi.org/10.29309/TPMJ/2020.27.11.5746

\section{INTRODUCTION}

The anal fissure is a longitudinal bust in the mucosa of the distal anal canal which extends from the anal verge proximally but not extending up to the dentate line. Acute anal fissures have short history less than 6 weeks and is characterized by drastic anal pain associated with defecation. Chronic fissures are characterized by a longer history usually more than 6 weeks. Chronic anal fissure have hypertrophied anal papilla internally and a sentinel tag externally between which lies the slightly indurated anal ulcer overlying the fibers of the internal sphincter.

The exact cause of anal fissures is not known. Anal fissures usually appear with local trauma caused by strenuous defecation due to hard stools. Internal sphincter hypertonia caused by continuing of these conditions. $40 \%$ with acute anal fissure will convert to chronic one..$^{1,2}$ It has been observed that constipation is the primary and sole cause of commence of a fissure. Transit of hard stool, irregularity of diet, use of spicy and pungent food, flawed bowel habits and deficiency of local hygiene can contribute for initiation of the pathology. In females the ailment is usually triggered during pregnancy and following childbirth. ${ }^{3}$ Manifestations from anal fissure causes considerable morbidity and reduction in quality of life in otherwise healthy individuals.

When chronic, patients may also complain of itching secondary to irritation from the sentinel tag or discharge from the ulcer. In $80 \%$ of patients classic anal fissure occur in posterior midline and remaining $20 \%$ in anterior midline. ${ }^{4}$ Atypical anal fissure or ectopic locations suggest a more sinister 
cause (Tuberculosis, cancer, Crohn's disease sexually transmitted, human immunodeficiency virus (HIV)-related ulcers syphilis, Chlamydia, chancroid, venereum, HSV, cytomegalovirus, Kaposi's sarcoma, B-cell lymphoma and squamous cell carcinoma. Mostly anal fissures are clinically diagnosed and there are several ways to treat them medically and surgically.

Healing of chronic fissure by conservative treatment occurs in about $50 \%$ of the patients. Surgical treatment is associated with the highest likelihood of prompt healing and low risk for recurrence. First internal sphincterotomy was initiated in 1951 by Eisenhammer who endorsed total division of internal anal sphincter. He amended this technique in 1959 narrating lesser division to dentate line. Which is safe and adequate.

Manual dilatation of anus is usually done to relax internal sphincter and to relieve symptoms of chronic anal fissure. Historically, under regional or general anaesthesia manual anal sphincter dilatation is done to reduce sphincter tone. Previously it was very a popular procedure in the treatment of chronic anal fissure. ${ }^{8}$ The purpose of this study was to compare the results of total lateral internal anal sphincterotomy and manual dilatation of anus in terms of symptoms and postoperative complications

\section{MATERIAL \& METHODS}

This randomized controlled prospective Cohort study. The sample size of this study was calculated using a sample size calculator $N=\frac{\frac{Z^{2} \sigma(1-\sigma)}{E^{2}}}{\text { Based }}$ on $a=0.05$ with sigma $=0.2$, power of test $p=0.9$ to detect a significant. It was conducted at Department of Surgery District Teaching Hospital Sargodha, Pakistan from April 2018 to Feb 2019. Approval for this study was taken from Research desk of Sargodha medical college and DHQ Hospital administration. 100 patients of chronic anal fissure with pain and bleeding in whom conservative treatment failed were selected by lottery method. Atypical fissures due to chronic causes like T.B, inflammatory bowel diseases, malignancy etc were excluded from study. The mean age of patients was 35 year ranging from 20 to 58 years. 90 patients location of fissures was posterior midline and in 10 it was located in anterior midline. Table-I

All patients had symptoms of chronic anal fissure for at least six weeks duration with sentinel pile or skin tag. Operations were performed on elective list under spinal or general anesthesia in lithotomy position after taking informed consent.100 patients divided into two groups with Group A, 50(36 male 14 female) patients underwent lateral internal sphincterotomy and Group B 50 (40 male 10 female) underwent manual dilatation of anus. In lateral internal sphincterotomy the internal anal sphincter was divided up to dentate line and in manual dilatation of anus the sphincter was dilated with gradual four finger technique to relax it. In LIAS technique we made the radial incision in inter-sphincter groove at 3 o' clock position. Gauze lubricated with mycetracin cream was placed and pad was applied which was removed on next morning after surgery. Most of the patients were discharged within 24 hours after surgery and were advised warm sitz baths, stool softeners agent for two weeks. Median follow up of 3 months was advised. During follow up the post-operative complications, persistence or relief of symptoms were recorded. Data was analyzed by using independent $\mathrm{T}$ test.

\section{RESULTS}

Among 100 patients with chronic anal fissure which were studied, 76 were male and 24 were female with male to female ratio 3.1:1. The mean age was 35 year ranging from 20 years to 58 years. In 50 patients (36 male, 14 female) lateral internal anal sphincterotomy and in other 50 .

\begin{tabular}{|l|c|c|c|}
\hline & $\begin{array}{c}\text { Anterior } \\
\text { Midline }\end{array}$ & $\begin{array}{c}\text { Posterior } \\
\text { Midline }\end{array}$ & Total \\
\hline Group A & 6 & 44 & 50 \\
\hline Group B & 4 & 46 & 50 \\
\hline \multicolumn{2}{|c|}{ Table-I. Anatomical site of anal fissure. } \\
\hline \multicolumn{2}{|c|}{} \\
\hline
\end{tabular}




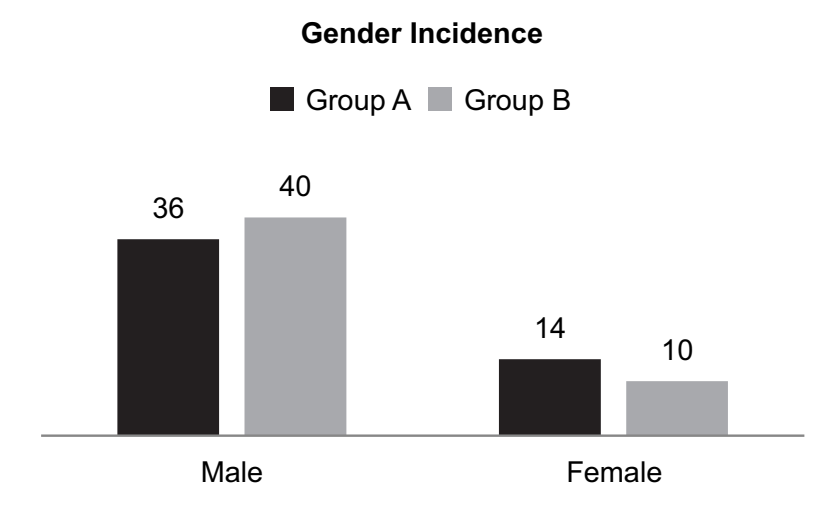

Table-II. Gender incidence.

\begin{tabular}{|c|c|c|c|}
\hline \multirow[b]{2}{*}{ Complications } & \multicolumn{3}{|c|}{ Technique/ Operation } \\
\hline & $\begin{array}{c}{ }^{*} \text { LIAS }{ }^{1} \\
n=50 \\
\text { (Group 1) }\end{array}$ & $\begin{array}{c}\text { **MAD }{ }^{2} \\
n=50 \\
\text { (Group 2) }\end{array}$ & $\begin{array}{c}\text { P. } \\
\text { Value }\end{array}$ \\
\hline Haemorrhage & - & - & - \\
\hline Urinary retention & $2(4 \%)$ & $2(4 \%)$ & 0.5 \\
\hline Perianal abscess & - & - & - \\
\hline Perinal fistula & - & - & - \\
\hline $\begin{array}{l}\text { Pain and bright- } \\
\text { red bleeding on } \\
\text { defaecation }\end{array}$ & - & $1(2 \%)$ & 0.15625 \\
\hline $\begin{array}{l}\text { Flatus } \\
\text { incontinence }\end{array}$ & $2(4 \%)$ & $2(4 \%)$ & 0.5 \\
\hline $\begin{array}{l}\text { Infection of } \\
\text { wound }\end{array}$ & - & - & - \\
\hline $\begin{array}{l}\text { Faecal } \\
\text { incontinence / } \\
\text { soiling }\end{array}$ & $1(2 \%)$ & - & 0.15625 \\
\hline $\begin{array}{l}\text { Fissure } \\
\text { recurrence }\end{array}$ & - & - & - \\
\hline Anal stenosis & - & - & - \\
\hline
\end{tabular}

\section{* LIAS' (lateral internal anal sphincterotomy) \\ ** MAD² (manual anal dilatation)}

Patients manual dilatation of anus was done, (40 male, 10 female) table-II. Mean hospital stay was 17 hours ranging from 12 to 24 hours. All patients of both groups became Symptoms free within one week of operation. Urinary retention was noted in four $4 \%$ patients $2(4 \%)$ in LIAS and $2(4 \%)$ in manual dilatation of anus which was transient and managed with conservative measures all were male and age was $>55$ years. Temporary flatus Incontinence was noted in $2(4 \%)$ patient of lateral internal sphincterotomy and $2(4 \%)$ in manual dilatation of anus. Faecal soiling was observed in $1(2 \%)$ patient of lateral internal anal sphincterotomy. All with temporary incontinence of flatus and faeces were female and had delivered children in near past and these patients recovered from this within one month of surgery with conservative measures. one patient suffered from bright red bleeding in manual dilatation of anus group. No patient suffered from recurrence, anal stenosis, wound infection and pain associated with defecation. 48 (96\%) Patients in LIAS and 49\% (98\%) in manual dilatation of anus group were satisfied with their operation.

\section{DISCUSSION}

The effectiveness of both techniques in chronic anal fissure treatment mainly rely on the relief of symptoms and post-operative complications. This small ulcer usually disturbs the routine activities so main focus of clinician should be to make patient symptom free. Both these procedures are very much effective in this regard.

Although all age groups and both gender are effected Kumar reported that the mean age of patient were 49.5 years $^{9}$ while Ebinger and other reported that it effects all age groups especially youngers. ${ }^{10,11}$ Our study included both age groups with more male than females and the mean age was 35 years which is also younger group.

The main aim of the study was to use best technique for the treatment of chronic anal fissure. We have adopted both techniques in this study with favorable results that is approximately 98- $100 \%$ cure rate regarding symptoms relief complications.

Aftab et al said that In addition to pain, chronic anal fissure influences psychological, social and physical well-being of the effected individuals. Lateral internal sphincterotomy not only eliminates anal pain but it also restores many aspect of quality of life. ${ }^{12}$ 
Zubair et al described that a variety of surgical procedures have been employed to treat chronic anal fissure however the best results have been reported with subcutaneous lateral internal sphincterotomy (SLIS) with a success rate of 90-95\% which are comparable with our results. ${ }^{13}$ Beside LIAS various other surgical procedures employed for managing chronic anal fissures which include manual anal stretch, controlled intermittent anal dilatation and fissurectomy. The manual anal stretch had been also common practice in the past. The major drawbacks of these surgical procedures have been the higher rates of fissure persistence and greater risk of incontinence.

Lateral internal sphincterotomy is an effective techniques but with a risk of temporary or permanent incontinence to flatus and feces. Popat reported flatus in continence in $2 \%$ population which is comparable with our study. ${ }^{11}$ Temporary incontinence to flatus occurred in 4 patients $2(4 \%)$ in lateral internal anal sphincterotomy and 2(4\%) in manual dilatation of anus.

Hareesh et al in a comparative study described that in Manual anal dilatation $3(10 \%)$ patients were experienced nocturnal soiling whereas in lateral anal sphincterotomy only 1 (3.3\%) patients had this complication. Sanni Yasin et al concluded 9\% incontinence rate in both open and closed method. We find fecal incontinence in1 (2\%) from LIAS which was female probably with weaker and shorter sphincter complex. one study showed favorable results in manual dilatation of anus as in our study ${ }^{14}$ but vaithiancithan reported one patients with this complications. ${ }^{15}$ In our study we did not faced fecal incontinence in manual dilatation of anus.

Closure of wound results in wound infection and abscess formation especially in closed methods of lateral internal sphincterotomy ${ }^{16}$ but we did not found such complications.

Recurrence rate is 4-6\% in difference studies. ${ }^{17,18,19}$ But we did not received any patients with such complications it may be due to poor follow up.
Four patients were having transit urinary retention 2 in both procedures which may be due to spinal/saddle anaesthesia ${ }^{20}$ mostly improved after warm sitz bath. Our results are compatible with international studies. We can't operate all patients without informed consent and the type of procedure selected for their treatment.

\section{CONCLUSION}

Because of approximately 95-98\% cure rate with lower rate of complications in both techniques and the greater satisfaction of the patient's. Both lateral internal anal sphincterotomy and manual dilatation of anus are the best treatment for chronic anal fissure.

Copyright@ 02 Sep, 2020.

\section{REFERENCES}

1. Choi YS, Kim DS, Lec DH, Lec JB, Lec EJ, Lec D et al Clinical characteristics and incidence of perianal disease in patients with ulcerative colitis. Ann Colo proct ol. 2018 Jun; 34 (3): 138-143.

2. Jamshaidi R. Anorectal complaints: Haemorrhoids, fissure abscess, fistulae. Clin colon rectal surgery. 2018 Mar; 31 (2): 117-120.

3. Singh M, Chandrakar S, Agrawal A et al; Anal fissure revisited; A systemic review. JEMDS 2015 July 58(4): 10226-37.

4. Abdul waheed M.S. Chronic anal fissure open lateral internal sphincterotomy results: A case series study. Annals Medicine and surgery. 2017; 15: 56-58.

5. Salem AE, Mohamed EA, Elghadban HM, Abdelghani GM. Potential Combination topical theraphy of anal fissure development, evaluation and civical study. Drug deliv. 2018 Nov; 25 (1): 1672-82.

6. Siddiqui J, Fowler GE, Zahid A, Brown K, Young CJ. Treatment of and fissure: A survey of surgical preatice in Australia and New Zealand. Colorectal Dis. 2019 Feb; 21 (2): 226-233.

7. Corter D, Dickman R. The role of botox in colorectal disorders. Curr Treat options Gastroenterol. 2018 Dec; 16 (4): 541-547.

8. Hareesh GSR et al. Comparative study of manual anal dilatation and lateral internal anal sphincterotomy in the treatment of acute anal fissure. int Surg J.2019 June; 6(6):2022-27. 
9. Kumar D, Anil N, Neeraj K, Avinash P. Prospective randomized study of comparison of lateral internal sphincterotomy versus Lord's anal dilatations in chronic and fissure. int Sur J. 2018; 5(3): 1028-30.

10. Ebinger SM, Hardt J, Warsch kow R, Schmied BM, Herold A, Post $S$ et al. Operative and medical treatment of chronic and fissure a review and network meta-analysis of randomized controlled trials. J Gastroenterol. 2017 June; 52 (6): 663-76.

11. Popat A, Pandey CP, Agawal K, Srivastava VP, sharma SM, Dixit A. A comparative study of role of topical diltiazem $2 \%$ organo gel and lateral internal sphincterotomy for the management of chronic and fissure in ano. Int $\mathrm{J}$ contemp Med Res. 2016; 3: 1363-5.

12. Aftab A B, Mahmood S M, Ahmad A. Close lateral internal sphincterotomy, an effective treatment for chronic anal fissure. PJMHS. Apr-jun2019; 13(2): 27678.

13. Zubair M, Sadiq M, Shah GA. Efficacy and safety of subcutaneous lateral internal sphincterotomy for chronic anal fissure. J Ayub Med Coll Abbottabad 2014; 26(2) 141-44.

14. Anandaravi B, Ramaswami B. Closed versus open lateral internal sphincterotomy in the treatment of chronic anal fissure. Inter surg J. 2017; 4 (3):1055-8.
15. Vaithianathan R, Paneerselram S. Randomized prospective controlled trial of topical $2 \%$ diltiazem versus lateral internal sphincterotomy for the treatment of chronic fissure in ano. Indian $\mathrm{J}$ surg. 2015; 77 (3): 148-7.

16. Singh M, Chandrakar S, Agrawal A, Singh G. Anal fissure revisited: A systematic review JEMDS. July 2015; 58 (4): 10226-10237.

17. Sahabally SM, Meshkat B, Walsh SR, Bedly D. Botulinum toxin injection Vs topical nitrates for chronic anal fissure an updated systematic review and meta-analysis of randomized controlled trials. Colorectal Dis. 2018 Jan; 20 (1): 6.15.

18. Salih AM. Chronic anal fissure: open lateral internal sphincterotomy result; A case trial study. Ann Med surg. 2017 Mar; 15: 56-58.

19. Liang J, Church JM. Lateral internal sphincterotomy for surgically recurrent chronic anal fissure. AM J Surg. 2015 Oct; 210 (4): 715-19.

20. Olfat EL, sabri A, Ahmad E, Ahmad O. A comparative study between lateral internal Sphinctertomy (An alternative approach) and fissurectomy in surgical management of chronic idiopathies and fissure. Menoufia Medical Journal. 2017; 30 (2): 383-387.

\begin{tabular}{|c|l|l|l|}
\hline \multicolumn{3}{|c}{ AUTHORSHIP AND CONTRIBUTION DECLARATION } \\
\hline Sr. \# & Author(s) Full Name & \multicolumn{1}{|c|}{ Contribution to the paper } & Author(s) Signature \\
\hline 1 & Allah Nawaz & $\begin{array}{l}\text { Selection of topic, allocation } \\
\text { of work to coauthors and data } \\
\text { collection. } \\
\text { Data collection, review of meterial. }\end{array}$ \\
\hline 2 & Khalid Mahmood & $\begin{array}{l}\text { References collection, writing, } \\
\text { editing, and submission of article. }\end{array}$ \\
\hline 5 & Ahmad Hassan Khan & $\begin{array}{l}\text { Data collection, review of } \\
\text { materials. } \\
\text { Data collection, review of } \\
\text { materials. } \\
\text { Data collection, review of } \\
\text { materials. }\end{array}$ \\
\hline 6 & Asad Rizwan Rana & Raza Farooq & \begin{tabular}{l} 
Natimat \\
\hline
\end{tabular} \\
\hline
\end{tabular}

